\title{
A Different Glance on Flies in Terms of Public Health or Why We Cannot Give Up on Flies?
}

\section{Cem Turaman MD*, MSc.}

Free-lance public health consultant. Public health specialist, Epidemiologist, Tropicalist, Entomologist, Cankaya Ankara, Turkey

*Corresponding Author: Cem Turaman, Free-lance public health consultant, Cankaya Ankara, Turkey

Received date: 18 February 2021; Accepted date: 01 March 2021; Published date: 05 March 2021

Citation: Turaman C, A different glance on flies in terms of public health or why we cannot give up on flies?. J Comm Med and Pub HealthRep 2(1): https://doi.org/10.38207/jcmphr20210010

Copyright: (C) 2021 Cem Turaman. This is an open-access article distributed under the terms of the Creative Commons Attribution License, which permits unrestricted use, distribution, and reproduction in any medium, provided the original author and source are credited.

\begin{abstract}
Background: The fly, as an abundant and widespread insect group, with its mouthparts developed during its evolution suitable to its nourishment, has long been an undesirable pest by humans because of its cosmopolite behavior and choice of nutriment.

Methods: A review of the literature on detriments and benefits of fly has been done through the internet, the "for" and "against" articles were compiled, categorized, and reviewed, and representative ones were selected as references.

Results: Today, at least in the scientific environments, the "pest approach" is in transformation, therefore we need to shift from observation toactively implement the role of the fly in keeping the environment clean. Controlled biowaste transformation, exploitation of the larval protein and fat, use of larva as livestock and human food, and production of a more environment friendly biodiesel can be a starting point of such implementations
\end{abstract}

Conclusion: For the benefit of humans, we should switch our long run hostility against the fly into a confident and fruitful relationship.

Keywords: Fly, vector, biowaste, nutrient, biodiesel

\section{Introduction}

Insect, with its three-sectioned trunk (Greek: Insects, singular septum), three double pairs of articulated legs, and two pairs of wings, as a rule, is a master of survival which can adapt itself to a wide range of nutritional and ecological niches. Due to its tiny size,it has been able to spread all over the planet. Insects have been grouped under about 30 orders, though the relevant taxonomic arguments continue [1]. One of these orders, Diptera, is the group that includes flies Diptera with approximately 90,000 identified species, is one of the largest insect groups on the Earth. Although theappearances of the flies drastically vary, they are characterized by apair of front wings and a pair of atrophied hind wings, called the 'haltere' which are believed to stabilize the flight. The mouths of theflies vary but their compound eyes are a common feature. Flies canbe found in almost all terrestrial habitats, even on the open seas, away from the land [2]. Most of the "Upper Diptera" which are defined as Brachycera that feeds on decomposing animals and vegetative substances, has spongingsucking mouthparts. The larvae of these flies are called maggots. These saprophyte- scavenger maggots keep the environment clean by feeding on decomposing vegetative and animal substances. Some

\section{Methods}

A review of literature on detriments and benefits of fly have beendone through the internet; the "for" and "against" articles, including the old adult flies are predators or parasites of other insect species and some help the plants to pollinate $[3,4]$. Thus, killing the flies will deprive us of having fruits and lead to excessive amounts of organic waste. Fliesare holometabolous insects that go through a four-stage whole metamorphosis: egg, larva, pupa, and adult. The larvae go through a series of molting or ecdysis while growing. The stage between the two moltings is called "instar" [5]. Over 350 fly species in twenty- nine different families are connected to food-borne diseases and over 50 synanthropic fly species live in unhealthy environments [6].Numerous species are considered pests for humans and livestock animals. Enormous investments are being done for the sake of human health and comfort concerning the control of house fly Musca domestica (Diptera: Muscidae) [7]. Face fly, Musca autumnalis, horn fly, Haematobia irritans, and stable fly, Stomoxys calcitrans are well known for their bites [2]. House flies play a significant role in transmitting many human diseases and is knownas domestic pests [8]. Lesser house fly, Fannia canicularis and latrine fly, Fannia scalaris are known for disturbing the people around houses and farms [9]

and new ones to realize the impact of time was compiled, categorized, and reviewed, and only representative oneswere selected as reference. 


\section{Results}

\section{The traditional points of view}

The flies have a reputation as mechanic and biologic vectors which transmit disease agents [7]. The mechanic way, subject of this manuscript, consists of the transmission of the pathogen organism without sexual reproduction, through the contaminated mouth or setae (tick hair) and tarsi (distal feet segments). Pathogen organisms are taken by the outer parts of the trunk of a fly from garbage, drains, or other dirt resources and/or collected in the anterior gut then carried back to mouth segments through vomiting and can betransmitted to humans or animal foods. Some pathogens, when swallowed by the fly, may reside in the mouth or gut channel for days and can be contaminated when the fly vomits or defecates. In this type of transmission, the pathogen microorganism is not sexually reproduced

\section{The other face of the fly}

Alongside the disturbing feature of the flies as transmitters ofdisease, they also have an important "environment-friendly" role asconsumers of human waste and animal carcass. The role of the fly as a forensic entomology agent has become important in recent years [3]. Maggot debridement therapy has become a widespread cure for chronic wounds [14]. Recent research has shown that fly maggots render the animal feces and garbage contaminated with harmful pathogens aseptic. Fly species whose larva consume and convert organic slaughterhouse, the marketplace, domestic, andlivestock farm wastes also eliminate the bad smells coming from these organic wastes and clean microorganism contamination, rendering it a favourite animal and human food [15]. The larva of M.domestica fed on organic municipality waste have a rich protein concentration, causes weight gain as efficient as the standard poultry forage [16]. Hermetia illucens (Diptera: Stratiomyidae)larva reduces the E. coli level in cow manure [17]. One problem which exists is the risk of heavy metal accumulation in the larva [18]. More than $40 \%$ of the H. illucens larva which transforms the waste through consummation is protein and $30 \%$ is fat. In this process, the manure weight reduces together with the nitrogen and phosphorus [19]. Moreover, this fly also prevents the reproduction of $M$. domestica in the manure [20]. Hermetia illucens is alsoefficient in processing waste stemming from fishery activities [21] and coffee production [22].

\section{Conclusions}

Fly is an insect unfairly defined as a pest-vector by humans becauseit shares our food. With its cosmopolitan behaviours it acquired in thousands of years, the fly has developed a life cycle which vastly depends on the human environment, therefore, drew a reaction from humans. Scientific circles -especially after Louis Pasteur- were primarily preoccupied with proving the harmful aspects of flies on human health; however today it is accepted that it would be impossible to cope with organic waste piles created because of human or developed on/in the body of the fly. Severalviruses, bacteria, fungi, protozoa, and nematodes are known for decades as examples of such pathogens [10]. These pathogens whichcan directly be transmitted to human food by house flies while theyfeed on fecal materials are Enteroviruses, Salmonella, Campylobacter, Escherichia, Enterococcus, Chlamydia, and manyother pathogen genus [4]. Even though these flies are mostly relatedto shigellosis epidemics [11] they might also be responsible for food poisonings, typhoid, cholera, tuberculosis, anthrax, ophthalmia, trachoma, and transmission of parasite worms [12]. Where sewage is carried on the ground, serious health risks might occur especiallyif there are food manufacturers, livestock farms, hospitals, or slaughterhouses around the area [13].

Biodiesel as a consumable and eco-friendly fuel oil is gaining importance throughout the world [23]. However, because its raw material is composed of oils which are extracted from waste food and cereals, its production is costly, a factor that limits its effectiveuse [24]. Production of biodiesel out of oils coming from restaurantwastes is less costly, however the waste bi-produced with this method is difficult to destroy. H. illucens enables the waste disposal of the biodiesel produced from corn [25]. Using raw material otherthan food is the most efficient method of obtaining biodiesel [26]. H. illucens larva which feed on restaurant wastes can be useful in biodiesel production too. The solid waste remaining from the restaurant waste once the oil is extracted can be used as fly larva forage which might also increase the efficiency. The performanceis reduplicated when Hermatia illucens larva is used for thispurpose; biodiesel produced out of the restaurant waste and the biodiesel produced out of the larva fed out of biodiesel productionwaste [26]. The fat content of the house flies is also high. Its larvacan be used as a biodiesel raw material when developed in pig manure. This also enables the transformation of pig manure and obtaining high-quality protein from the larva. The biodiesel produced out of house fly larva reared in pig manure contains the desired methyl ester profile and conforms to the ASTMD6751-10 standards [27]. Housefly larva is a cheap potential in biodiesel production [28].

activities, without the help of flies and more articles on the subject are being published. Preventive medicine professionals, even though they call themselves "public health professionals"probably because they have the "community medicine" identity in many countries, have also become one of the occupational groups which aspire to cope with flies. However today, the important role of the flies in the disposal of human and animal wastes thanks to their saprophyte/scavenger nutritional habits is widely accepted. Now is the time to actively begin 
to use this potential of the flies apart from just observing it. Making use of their biproducts such asprotein, fat, and biodiesel, the produced biowaste can largely be managed. It would be for the benefit of the

\section{Key Points:}

- The fly has developed a life cycle which depends on human environment, is unfairly defined as a pest-vector.

- After the Pasteurian revolution, the scientific circles were primarily preoccupied with proving the harmful aspects of flies on human health.

Conflict of Interest: No other conflict of interest.

\section{References}

1. Triplehorn, C.A., Johnson, N.F., D J (2005) Borror and DeLong's Introduction to the Study of Insects. Seventh Ed. Brooks/Cole California. 1-98

2. McAlpine JF, Peterson BV, Shewell GE, Teskey HJ, Vockeroth JR, et al. (1981) Manual of Nearctic Diptera, Vol 1. Research Branch, Agriculture Canada No.27, 9-89

3. Byrd JH, Castner JL. (2010) Forensic Entomology The Utility of Arthropods in Legal Investigations, Second Edition CRC Press Florida. 17-126

4. Service M. (2012) Medical Entomology for students. Cambridge University Press, Fifth Edition.

5. Gilbert L. (2009) INSECT DEVELOPMENT morphogenesis, molting and metamorphosis. Academic Press Massachusets.

6. Imai C. (1985) A New Method to Control Houseflies, Musca domestica, at waste disposal sites. Research in Population Ecology. 27: 111-123.

7. Matthews G. (2011) Integrated Vector Management. John Wiley $\&$ Sons New Jersey.

8. Malik A, Singh N, Satya S. (2007) House fly (Musca domestica): A review of control strategies for a challenging pest, Journal of Environmental Science and Health Part B 42(4):453-469

9. Bishoff FC, Dove WE, Parman DC. (1915) Notes on certain points of economic importance in the biology of the house fly. Journal of Economic Entomology 8(1): 54-71

10. Nuorteva P. (1959) Studies on the significance of flies in the transmission of poliomyelitis. The composition of the blowfly fauna in different parts of Finland during the year Ann. Entomol. Fenn.25: 137-162.

11. Levine OS, Levine MM. (1991) House flies (Musca domestica)as mechanical vectors of shigellosis. Reviews of Infectious Diseases 13(4): 688-696.

12. Förster M, Klimpel S, Sievert K. (2009) The house flies (Musca domestica) as a potential vector of metazoan parazites caught ina pig-pen in Germany. Veterinary Parasitology 160(1-2): 163-167.

13. Ostrolenk M, Welch H. (1942) The house fly as a vector of food humans to establish a reliable and effective relationship with the flies through a "socialcontract" and leave aside the long-lasting hostility we have been bearing against them.

- Today it is accepted that it would be impossible to cope with organic waste piles without the help of the fly.

- Making use of their biproducts such as protein, fat, and biodiesel, the produced biowaste can be better managed.

poisoning organisms in food producing establishments. American Journal of Public Health 32(5): 487-494.

14. Dumwille JC, Worthy G, Bland JM, Cullum N, Dowson C, et al. (2009) Larval therapy for leg ulcers (VenUS II): randomised controlled trial. BMJ. 338: b773

15. Ramos-Elorduy J. (1997) Insects: A sustainable source offood? J. Ecology of Food and Nutrition 36(2-4): 247-276

16. Ocio E, Viñaras R, Rey JM. (1979) Housefly larvae meal grown on municipal organic waste as a source of protein in poultry diets. Animal Feed Science and Technology 4(3): 227-231.

17. Liu Q, Tomberlin JK, Brady JA, Sanford MR, Yu Z. (2008) Black Soldier Fly (Diptera: Stratiomyidae) Larvae ReduceEscherichia coli in Dairy Manure, Environmental Entomology 37(6):15251530

18. Diener S, Zurbrügg C, Tockner K. (2009) Conversion of organic material by Hermetia illucens larvae: Establishingoptimal feeding rates. Waste Management and Research 27(6):603-610

19. Newton GL, Sheppard DC, Watson DW, Burtle GJ, Dove CR,et al. (2005) The Hermetia illucens, as a manure management/ resource recovery tool. Report

20. Sheppard DC, Newton GL, Thompson SA, Savage S. (1994) A value added manure management system using the Hermetia illucens. Bioresource Technol. 50(3): 275-279

21. St-Hilaire S, Cranfill K, Mcguire MA, Mosley EE, TomberlinJK, et al. (2007) Fish Offal Recycling by the Hermetia illucens Produces a Foodstuff High in Omega-3 Fatty Acids. Journal ofthe World Aquaculture Society. 38(2): 309-313.

22. Lardé G. (1990) Recycling of coffee pulp by Hermetia illucens(Diptera: Stratiomyidae) larvae. Biological Wastes (33)4: 307310

23. Fangrui M, Milford AH. (1999) Biodiesel production: A review. Bioresource Technology 70(1): 1-15

24. Marchetti JM, Miguel VU, Errazu AF. (2007) Possible methods for biodiesel production Renewable and Sustainable Energy Reviews (11)6: 1300-1311 
25. Li Q, Zheng L, Cai H, Garza E, Yu Z, et al. (2011) From organic waste to biodiesel: Black soldier fly, Hermetia illucens, makes it feasible. Fuel 90(4): 1545-1548

26. Zheng L, Li Q, Zhang J, Yu Z. (2012) Double the biodiesel yield: Rearing black soldier fly larvae, Hermetia illucens, on solid residual fraction of restaurant waste after grease extraction for biodiesel production. Renewable Energy 41(1): 75-79

27. Standard Specification for Biodiesel Fuel Blend Stock (B100) for MiddleDistillate Fuels [editorial] (Accessed June 2020)

28. Yang S, Li Q, Gao Y, Zheng L, Liu Z. (2014) Biodiesel production fromswine manure via housefly larvae (Musca domestica L.), Renewable Energy 66(C): 222-227 